Ann. Biol. anim. Bioch. Biophys., I975, 15 (2), 345-352.

\title{
THE USE OF PROGESTAGENS AND PHOTOPERIODISM IN IMPROVING THE REPRODUCTIVE RATE OF THE EWE
}

\author{
J. J. ROBINSON, C. FRASER and I. McHATTIE \\ Rowett Research Institute, \\ Bucksburn, Aberdeen AB2 9SB (Scotland)
}

\section{SUMMARY}

\begin{abstract}
A brief description of an intensive unit in which Finnish Landrace $\times$ Dorset Horn ewes are bred to Suffolk rams every 205 days, to produce lambs which are abruptly weaned at four weeks of age on to cereal-based diets, is given. The unit combines photoperiodism and hormone treatment for the induction and synchronisation of oestrus respectively. The photoperiod treatment consists of an abrupt increase in daylength to 18 hours at 60 days of gestation followed by a daily reduction of $3 \mathrm{I} / 2 \mathrm{mn}$ from 90 days of gestation. Hormone treatment is in the form of intravaginal pessaries impregnated with $30 \mathrm{mg} 9 \alpha$-fluoro-II-hydroxy-I $7 \alpha$-acetoxy progesterone (SC-988o, G. D. Searle) and $400 \mathrm{mg}$ progesterone. The overall mean conception rate for five consecutive reproductive cycles was $87.8 \mathrm{p}$. Ioo and the mean litter size 2.1 resulting in an average annual production of 3.5 lambs per ewe. Despite the continuous careful control of the artifical daylength regime an innate natural seasonal effect on the onset of behavioural oestrus after pessary withdrawal was noted and is discussed.
\end{abstract}

\section{INTRODUCTION}

Since the work of YEATES (I949) demonstrating that the onset of the breeding season of the ewe could be modified by altering the daily light to dark ratio, most studies have centred either on the neuroendocrinological mechanisms of photoperiodism (see review by DoNovaN, I967) or on the effectiveness of various gradual or abrupt decreases in daylength on the initiation of behavioural oestrus. (HART, I950; HAFez, I952 ; MAUleon and Rougeot, I962 ; Thibault et al., Ig66; Fraser and LAING, I969; DUCKER et al., I970 ; WILliams, I969).

In contrast there have been few studies on the effectiveness of repeatedly using an artificial lighting regime to improve the life-time reproductive performance of the ewe. This is perhaps not surprising since the variation in the onset of the artifi- 
cially induced oestrus is often large (DUCKER and Bowman, I970). The latter makes the precise control of the management and nutrition of the flock, considered necessary for the attainment of maximum individual ewe performance (RoBINson, I974) difficult. In this situation an effective means of synchronising oestrus is of obvious benefit yet studies on the combined use of photoperiodism and hormone treatment are limited (RoBINson and GiLL, I97I).

The present paper gives results for conception rate and litter size in ewes repeatedly subjected to a photostimulation regime in combination with exogenous hormones for the synchronisation of oestrus.

\section{MATERIALS AND METHODS}

A general description of the procedures used was given by RoBIsson (I97 4 ). In the present paper emphasis will be given to those aspects pertinent to the photostimulation and hormone treatment procedures.

The experiment was carried out at latitude $57^{\circ}$ I $\mathrm{O}^{\prime} \mathrm{N}$. Two groups (I and 2) each of $4^{S}$ unselected Finnish Landrace ( $\sigma^{\prime}$ 's) $\times$ Polled Dorset Horn (O's)were used. At the start of the experiment each group comprised three main age cate gories of approximately 8, 5 and 22 months. Depending on age, the ewes within each group were being exposed to the ram for cither the first, second or third time.

The ewes in Group I were synchronised in oestrus in October 1970, and those in Group 2, 102 days later in February 1971. Both these synchronisations occurred under natural daylength conditions and merely formed suitable starting points for the subsequent photostimulation regime. Immediately after mating each group of ewes was brought indoors and housed in separate units in which daylength was controlled artificially.

\section{Oestrus synchronisation}

Polyurethane intra vaginal pessaries (Roвinsov, I967) impregnated with 3omg 9x-fluoro-I Ihydroxy, I $7 \alpha$-acetoxy progesterone (SC-9880, G. D. Searle) plus $400 \mathrm{mg}$ progesterone dispersed in fine crystals throughout the pessary as described by GoRDon (197I) and dusted with an antibiotic preparation containing oleandomycin phosphate and tetracycline hydrochloride (Sigmamycin, Pfizer Ltd.) were used for the synchronisation of oestrus. For the initial matings, 50o IU's PMSG were given at pessary withdrawal.

The synchronisation of Group I ewes after their first full cycle of photostimulation involved a comparison between o and 500 IU's PMSG. Subsequent synchronisations were restricted solely to the pessary treatment except in those instances where ewes failed to show oestrous activity within four days of pessary withdrawal, in which case, the pessary treatment was immediately repeated and 500 IU's PMSG given at pessary withdrawal.

The pessaries were inserted for a period of i 2 days and immediately after their withdrawal the ewes were exposed to vasectomised rams for a period of 48 hours. Each ewe was then observed to be mated twice during her oestrous cycle by Suffolk rams using a procedure similar to that described by JENNINGS and CROWLEY (1970). The interval between matings was approximately 12 hours. Ewes which did not show behavioural oestrus or failed to conceive were exposed to fertile rams twice daily during the period 15 to 2 I days after the induced oestrus. Ewes which did not conceive to either of these two matings remained barren until the next reproductive cycle.

The lambs were abruptly weaned on to concentrate diets at 28 days of age and the ewes synchronised in oestrus again to give a reproductive cycle length of 205 days.

Ram management

Throughout the experiment the rams were kept under natural daylength conditions but were exposed periodically to two ovariectomised ewes which were induced into oestrus using oestrodiol benzoate. 


\section{Photoperiodism}

The natural daylength pattern together with the artificial pattern used for each group of ewes are given in figure I. It should be noted that the pattern is similar for each group of ewes but with a displacement of 102 days. Following the abrupt increase to 8 hours at 60 days after the synchronised oestrus and the maintenance of this level to go days, there was a gradual decrease in the light period of 3.5 minutes per day. This means that irrespective of the time of year at which the ewes lambed they were always mated at a daylength equivalent to that of October under natural conditions.

The average light intensity at the level of the eves was approximately i fo lux.

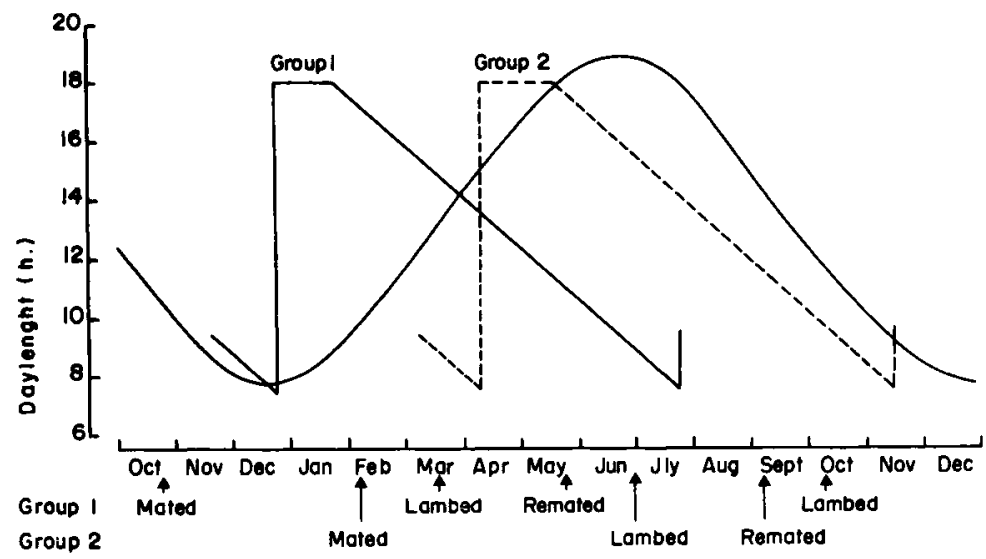

Iirc. t. - The artificial daylength patterns used for each group of ewes in velation to the natural pattern

\section{RESUL'TS}

The ewes in group I lambed in late March, early April and completed their first full reproductive cycle under artificial daylength conditions in May, i.e. the normal period of anoestrum. Their mean conception rates to the May mating, i.e. the first mating at the reduced lambing interval of 205 days are given in table $\mathrm{I}$.

On the basis of the results given in table I the PMSG was omitted from subsequent cycle and only re-introduced as a " recovery measure " where ewes failed to show behavioural oestrus after pessary withdrawal.

The combined conception rates for the induced and first repeat oestrous cycles together with the mean litter sizes for each group of ewes at each of the five matings are illustrated, in relation to time of year at mating, in figure 2 . 'Throughout the study a relatively high conception rate was maintained; the range being 82.2 to 97.9 p. Ioo with an overall mean of 87.8 p. roo. Within each group there was a general tendency for the percent conception to decrease from the first to the fifth reproductive cycle, with no definite indication of a seasonal effect.

Mean litter sizes were within the range I.95 to 2.35 with an overall mean of 2.I. Omitting the value for litter size for the group I ewes in their first cycle since it was 
influenced by the PMSG treatment (table I), then there was a suggestion that litter size was higher in the period of normal cyclic activity, than during the period of anoestrus under natural daylength conditions.

TABLE I

Conception rates and litter sizes in ewes subjected to photoperiodism and hormone treatment for the induction of oestrus in the normal period of anoestrus and at a reduced lambing interval of 205 days

(Date of induced oestrus, 2 Ist May r971)

\begin{tabular}{|c|c|c|c|c|c|c|c|}
\hline \multirow{2}{*}{$\begin{array}{l}\text { Number } \\
\text { of ewes }\end{array}$} & \multirow{2}{*}{$\begin{array}{l}\text { Hormone } \\
\text { treatment }\end{array}$} & \multirow{2}{*}{$\begin{array}{l}\text { Number of ewes } \\
\text { exhibiting oestrus } \\
\text { after pessary } \\
\text { withdrawal }\end{array}$} & \multicolumn{4}{|c|}{ Conceptions } & \multirow{2}{*}{$\begin{array}{c}\text { Mean } \\
\text { litter size }\end{array}$} \\
\hline & & & $\begin{array}{l}\text { Induced } \\
\text { oestrus }\end{array}$ & $\begin{array}{l}\text { repeat } \\
\text { oestrus }\end{array}$ & Total & p. 100 & \\
\hline $2_{t}^{\prime}$ & $\begin{array}{l}\text { Pessary } \\
+500 \mathrm{IU} \\
\text { PMSG }\end{array}$ & $2 / 4$ & 21 & 1 & 22 & 91.7 & 2.36 \\
\hline $2{ }^{\prime}$ & Pessary & 24 & 22 & 1 & 23 & 95.8 & 2.17 \\
\hline
\end{tabular}

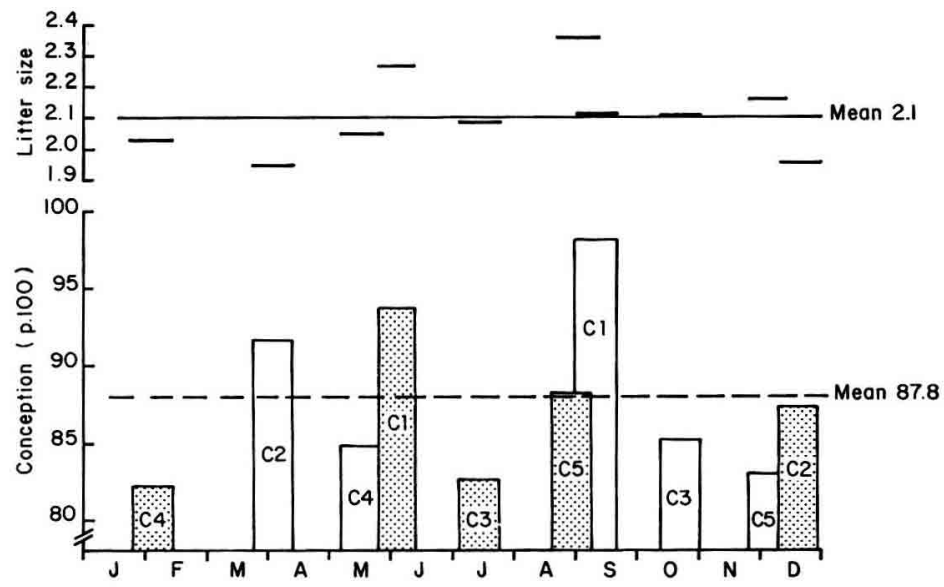

FIG. 2. - Conception rates and litter sizes in relation to time of year of mating for the two groups of ewes for five consecutive reproductive cycles, $C_{1}$ to $C_{5}$, each of 205 days duration

Group I ; grey Group 2 : white

The total lamb production for the original 96 ewes is given in table 2 . A total of 89 ewes or $92.7 \mathrm{p}$. Ioo conceived in either 3,4 or 5 of the 5 possible cycles and produced an average of 3.4 lambs per ewe per year. The question of the most valid way of expressing the average annual lamb production for each ewe in long term studies presents a problem. For this reason a number of alternatives are presented 
in table 2. The first gives an estimate of the reproductive performance of the original 96 ewes on the assumption that all 96 ewes were available for breeding in all five cycles and uses the period from first to sixth mating in calculating the average annual lamb production. The second method is similar to the first but uses the period from first mating to fifth lambing in calculating annual production. The third and fourth methods are probably the most valid in that ewe deaths are taken into account in the calculation.

TABLE 2

Data on the reproductive performance of 96 ewes subjected to photoperiodisn and hormone treatment for five consecutive reproductive cycles, each of 205 days duration

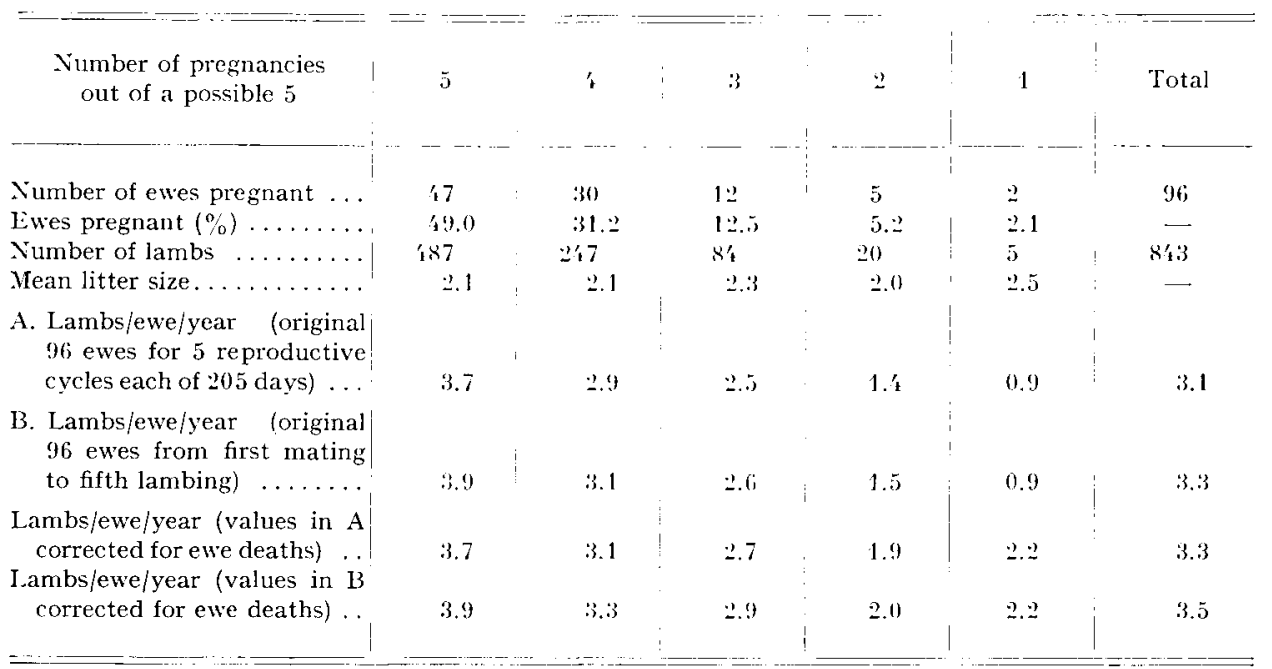

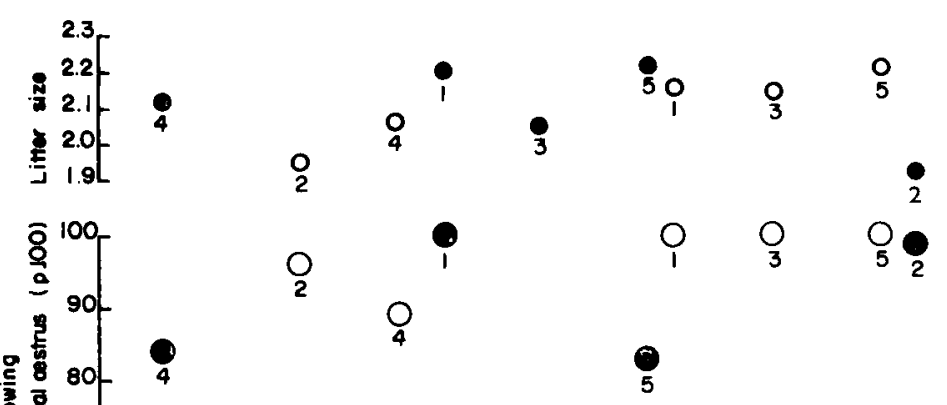

FIG. 3. - The effect of time of year at mating and reproductive cycle number (I to 5) on the percentage of ewes showing behavioural oestrus

after pessary withdrat'al

- Group I ; $\quad$ O Grollp 2 
In the context of the present paper it is of interest to present the effects of time of year and reproductive cycle number on the incidence of behavioural oestrus following pessary withdrawal at the first oestrus in each reproductive cycle.

In general, apart from the first mating of group I ewes, all subsequent matings for both groups in the natural period of anoestrus were associated with a slower onset of behavioural oestrus after pessary withdrawal than matings during the natural oestrous period, $i$. $e$. September to December. As shown in figure 3 this resulted in a proportion of ewes not showing behavioural oestrus within four days of pessary withdrawal, particularly during those months in which it would be normal to recommend the use of gonadotrophin for the induction of oestrus in ewes kept under natural daylength conditions. Although the associated litter sizes were not dramatically depressed, when the value for group I cycle I which contained a gonadotrophin effect was omitted, there was a tendency for them to be lower in the period corresponding to anoestrus under field conditions.

\section{DISCUSSION}

Before discussing the significance of the present results it should be made known that they are merely average values for a number of different nutritional treatments. For this reason, they should not be regarded as indicative of the maximum reproductive potential of the ewes. That said, they do raise a number of points which merit comment.

It can be legitimately argued that the absence of a control flock makes it difficult to draw precise conclusions on the relative effects of the photoperiodic and hormone regimes, or indeed on the interacting effects of ewe nutrition and other management criteria. What cannot be disputed is that irrespective of the method used to calculate the average long term reproductive performance of the ewes, it is of such a magnitude as to put beyond question the value of a wholly integrated approach in assessing the ewe's reproductive potential. In establishing this integrated approzch we were dependent on the results of numerous individual short term studies on the induction of oestrous activity by photoperiodism (see introduction for references) and on the separate studies undertaken to test the effectiveness of different prozestagens in the induction and synchronisation of oestru; (RoBrsson, I967; Grordox, I970).

In this context photoperiodic regimes similar to that used in the present study have been shown, in the short term, to be highly effective in the induction of a fertile oestrus in the normal anoestrous period. Indeed the excellent synchronisation of oestrus and the high conception rates observed in group I ewes after their first full cycle of photostimulation (table 1 ), support these short term observations. The subsequent slow onset of oestrous activity after pessary withdrawal with a proportion of ewes not exhibiting behavioural oestrus during the natural period of anoestrus, draws attention to the danger of extrapolating short term observations to long term production systems. In the present study the omission of gonadotrophin coupled with a reproductive cycle length of 205 days enabled this apparent long term seasonal effect to be observed, yet allowed sufficient time for the re-introduction of gonado- 
trophin as a "recovery measure " to effectively maintain long term productivity.

There is little doubt that the delay in the onset of oestrous activity during the period corresponding to anoestrus under natural daylength was in part due to long term nutritional effects. Nevertheless, the ability of group 2 ewes to exhibit roo p. Ioo oestrous activity in reproductive cycles 3 and $5, i . t^{\prime}$. in the natural breeding season, after showing a depression in cycles 2 and 4 , i.c. the normal period of anoestrus, again supports an underlying seasonal effect geared to natural daylength conditions. While these observations may appear surprising it is of interest to note that THIBAUL.T et al. (I966) and more tecently DUCKER (I97I), presented evidence for an inherent seasonal rhythm in oestrous activity in ewes kept on constant daylength patterrs. Also L,INZEL, (I973) has reported innate seasonal oscillations in the rate of milk secretion in goats kept under artificial daylength conditions.

In conclusion, the present study has demonstrated the merit of an integrated and long term approach to the problem of increasing the reproductive rate of the ewe. The approach has not only revealed new ceillings of production but has demonstrated the need for a greater understanding of the relative importance, both in the long and short term, of photoperiodism and hormone therapy, to mention but two of the factors under control in the intensive unit described. It is these aspects that are now receiving our attention.

Colloque: Control of sexual cycles in domestic animals.

October 27-30, 1974, Nouzilly.

\section{ACKNOWLEDGEMENTS}

Thanks are due to Miss C. CARxiE for her help in collating the data and Mr J. C. GiLl and members of the Duthie Experimental Farm for their care of the ewes. The advice of Professor I. Gornor, Cniversity College, Dublin on the hormonal aspects is also acknowledged.

\section{RÉSUMÉ,}

\section{UTII,ISATION DES PROGESTAGÈNES ETT DU PHOTOPÉRIODISME POUR ACCROÎTRE} I,ES POSSIBIIITÉS DE I,A REPRODUC'TION DE I,A BREBIS

L'auteur décrit une installation intensive dans laquelle on accouple des brebis issues du croisement Landrace finlandais $\times$ Dorset Horn avec des béliers Suffolk tous les 205 jours pour la production d'agneaux. Ceux-ci sont sevrés brutalement à l'âge de quatre semaines et doivent s'adapter à un régime à base cle céréales. Dans cette installation, on utilise à la fois un traitement photopériodique et un traitement hormonal dans le but d'effectuer, respectivement, l'induction et la synchronisation de l'oestrus. I.e traitement photopériodique consiste en une augmentation brusque de la longueur des jours jusqu'à is heures après le $60^{\mathrm{e}}$ jour de gestation, suivie d'une réduction quotidienne de $3 \mathrm{I} / 2$ minutes à partir du $90^{e}$ jour de gestation. Le traitement hormonal s'applique sous la forme d'éponges intravaginales imprégnées de $30 \mathrm{mg}$ de $9 x$-fluoro-I 7 -hydroxyI $7 \propto$-acetoxy progestérone ( $\mathrm{SC}-9880, \mathrm{G}$. D. Searle) et de ${ }_{4} 00 \mathrm{mg}$ de progestérone. Le taux moyen de conception établi pour un total de cinq cycles successifs de reproduction a été de 87,8 p. IOO, avec une moyenne de 2 , I agneaux par portée, ce qui représente une production annuelle moyenne de 3,5 agneaux pour chaque brebis. En dépit du contrôle continu et soigneux du régime lumineux artificiel, on a constaté néanmoins une influence innée et naturelle exercée par les saisons sur le déclenchement du comportement d'oestrus, une fois que les éponges ont été retirées. Ce phénomène est discuté. 


\section{REFERENCES}

Donovan B. T., I967. Control of follicular growth and ovulation. In: Lamming G. E. and Amoroso E. C. Reproduction in the Female Mammal, Chapter I, 3-29. London, Butterworths.

Ducker M. J., I97r. Photoperiodism in the ewe. Ph. D. Thesis. University of Reading.

Ducker M. J., Bowman J. C., I97o. Photoperiodism in the ewe. IV. A note on the effect on onset of oestrus in Clun Forest ewes of applying the same decrease in daylength at two different times of the year. Anim. Prod., 12, 513-5I6.

Ducker M.-J., Thwaites C. J., Bowman J. C., I97o. Photoperiodism in the ewe. II. The effects of various patterns of decreasing daylength on the onset of oestrus in Clun Forest ewes. Anim. Prod., 12, II 5 -I 23 .

Fraser A. F., Laing A. H., I969. Oestrus induction in ewes with standard treatments of reduced natural light. Vet. Rec., 84, 427-430.

GoRdon I., I970. Controlled breeding in sheep-its potential application under Irish farming conditions. Ir. Vet. J., 24, 227-24I.

Gordon I., I97r. Induction of early breeding in sheep by standard and modified progestagen-PMS treatments. J. agric. Sci, 76, 337-341.

HAFEZ E. S. E., I952. Studies on the breeding season and reproduction of the ewe. J. agric. Sci. 42, $189-265$.

HART D. S., I950. Photoperiodicity in Suffolk sheep. J. agric. Sci., 40, I43-I49.

Jennings J. J., Crowley J. P., ig7o. The mating of hormone treated sheep. Anim. Prod., 12, 357 (abstr.).

LINZELL J. L., I973. Innate seasonal oscillations in the rate of milk secretion in goats, J. Physiol., 230, 225-233.

Mauleon P., Rougeot J., 1962, Régulation des saisons sexuelles chez des brebis de races différentes au moyen de divers rhythmes lumeneux. Annls Biol. anim. Biochim. Biophys., 2, 209-222.

Robinson J. J., 1974. Intensifying ewe productivity. Proc. Br. Soc. Anim. Prod., 3, 3 I-40.

Robinson J. J., Gill J. C., I97I. A note on observations on the effect of photostimulation and hormone treatment on the oestrous activity and lambing performance of North Country Cheviot ewes. J. agric. Sci., 78, 343-345.

Robinson T. J., I967. The control of the ovarian cycle in the sheep. Sydney University Press.

Thibault C., Courot M., Martinet L., Mauleon P., du Mesnil du Buisson R., Ortavant R., Pelietier J., Signoret J. P., I966. Regulation of breeding season and estrous cycles by light and external stimuli in some mammals. In Environmental influences on Reproductive Processes. J.Anim. Sci., 25, Suppl., I I9-I42.

Williams H. Ll., r969. An assessment of the role of photostimulation in the modification of the. breeding season of sheep. Anim. Prod., 11, 283-284.

YEATES N. T. M., I949. The breeding scason of the sheep with particular reference to its modification by artificial means using light. J. agric. Sci., 39, I-43. 